\title{
Twórczość białoruskiego artysty ulicznego Andrieja Busła
}

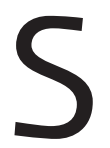

ztuka ulicy zarówno w kontekście społeczno-kulturowym, artystycznym, jak i aksjologicznym, jest zjawiskiem złożonym i niejednoznacznym. Z jednej strony, jest ona akceptowana i cieszy się zainteresowaniem badaczy wielu dyscyplin, mediów, samych artystów, jak i odbiorców, z drugiej - prace i działania twórców ulicznych wciąż są niedoceniane. Na rynku wydawniczym pojawia się coraz więcej pozycji na temat graffiti i street artu wśród których dominują wydania albumowe $\mathrm{z}$ autokomentarzem i wypowiedziami najważniejszych artystó $\mathrm{w}^{1}$ lub tekstami o genezie i historii street artu w danym kraju, np. w Polsce 2 . Autorzy badający ten światowy fenomen sztuki współczesnej koncentrują uwagę na zagadnieniach natury teoretycznej popartej badaniami jakościowymi³ ${ }^{3}$ opisują wybrane problemy street artu i graffiti w aspekcie związków słowa z obrazem i działaniem ${ }^{4}$, czy też proponują uznanie street artu jako „kategorii komunikacyjnej, aktualizowanej w konkretnych praktykach"5. Niewiele natomiast pisze się o twórcach graffiti i street artu działających w przestrzeni społeczno-kulturowej współczesnych miast Litwy, Łotwy, Białorusi, Ukrainy, Rosji, chociaż pojawiają się pozycje omawiające graffiti i street art na poziomie relacji obraz - słowo ${ }^{6}$.

Artykuł jest poświęcony niezbadanym dotychczas reprezentacjom i różnorodnym konkretyzacjom zróżnicowanej działalności artystycznej białoruskiego artysty ulicznego Andrieja Busła (pseudonim Hutkasmachna). Analiza wybranego materiału egzemplifikacyjnego, pochodzącego ze źródeł internetowych, została oparta na problemowych wyznacznikach interpretacyjnych, koncentrujących się wokół form aktywności twórczej artysty:

Wieczne w przemijającym. Dzieła mistrzów sztuki europejskiej w przestrzeni publicznej Mińska, Z ulicy do galerii. Wokół zagadnień odbioru sztuki ulicznej, Zawłaszczanie miejskiej przestrzeni: obiekty, instalacje, interwencje.

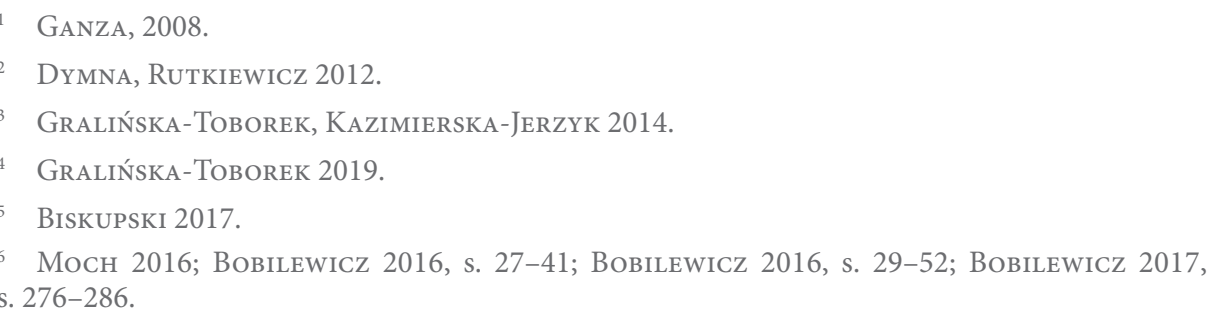


TECHNE

T E X N H

SERIA NOWA

\section{Wieczne w przemijającym. Dzieła mistrzów sztuki europejskiej w przestrzeni publicznej Mińska}

Od wielu lat białoruski artysta uliczny i architekt Andriej Busieł (pseudonim Hutkasmachna) ${ }^{7}$ umieszcza postaci i fragmenty $z$ dzieł mistrzów sztuki europejskiej na zewnętrznych lub wewnętrznych ścianach porzuconych, zdewastowanych budynków, brudnych obiektów, ruin, w zaniedbanych miejscach Mińska. Interesuje go szczególnie epoka Odrodzenia, którą uważa za „unikalny logotyp sztuki w świadomości człowieka”. Działania streetartowe Busły potwierdzają tezę Ernesta H. Gombricha, że sztuka rodzi się ze sztuki, a artysta fascynuje się tym, co jest mu znane, przekształca schematy i czerpie z doświadczeń swoich poprzedników. Busieł odwołuje się do mało znanych dzieł o tematyce mitologicznej, sakralnej i świeckiej. Głównie cytuje i interpretuje fragmenty zaginionych obrazów, które zachowają się dzięki szkicom do nich lub kopiom. Inspiruje się także freskami, malarstwem ołtarzowym i tablicowym, grafiką, ilustracjami, starymi grawiurami, sztychami i mapami itp. Opierając się na założeniu, iż ulice białoruskich miast, głównie Mińska, mają unikalny kontekst wewnętrzny i nie ma na nich odpowiednich płaszczyzn, żeby realizować graffiti, Busieł starannie opracowuje lokalizację swoich prac. Bada kulturową matrycę zastanego miejsca, uwzględnia jego aspekty historyczne, architektoniczne, topograficzne, historię krajobrazu kulturowego, wykorzystuje charakter odnalezionego miejsca, uwypukla jego dostrzegalne, bądź odkrywa ukryte walory wizualne i znaczeniowe, przetwarza i prezentuje. Jego prace, które można zaliczyć do gatunku site-specyfic, są przemyślane, wizualnie atrakcyjne, ale wykonane w miejscach niewidocznych, opuszczonych mają mniejszą siłę oddziaływania na odbiorców. Z drugiej strony, ich obecność w częściach miasta, które pozostają zwykle na marginesie, sprawia, iż dla przypadkowego przechodnia stają się głównym elementem odczytu. Wkomponowywanie przedstawień dawnych mistrzów w obszary miasta okryte złą sławą rodzi pytania - czy piękno potrzebuje brzydoty? czy jest to sztuka czy też próba estetyzacji (żeby było ładnie), czy streetartowe opracowania mają zacierać różnicę między sztuką a rzeczywistością, czy wręcz przeciwnie - różnicę tę wyostrzyć.

Busieł wykorzystuje przestrzeń miejską jako medium-nośnik dla autoekspresji i jako materiał artystyczny. Ściany traktuje jak płótno, płaszczyznę umożliwiającą wypowiedź artystyczną. Sztukę uliczną utożsamia z działaniem, które jest źródłem przyjemności dla artysty i odbiorcy. Streetartową rzeczywistość projektuje podobnie jak futuryści - jako zabawę i efekt niespodzianki. Jego prace przeznaczone są zarówno dla odbiorcy wrażliwego na piękno sztuki, jak i obeznanego ze sztuką; mają działać jednocześnie na zmysły (jako przekaz estetyczny) i na wyobraźnię, budzić skojarzenia lub skłaniać do refleksji. Wzorując się na renesansowych twórcach, Busieł dąży, by jego prace zbliżyły się do rzeczywistości, wtopiły się w trójwymia-

\footnotetext{
„Hutka-smaczna” (szybko, smacznie) - działające na białoruskich ulicach kioski z jedzeniem, które zostały zamknięte ze względu na nieodpowiedni standard zbiorowego żywienia. W Mińsku działa dziś tylko kilka nowoczesnych pawilonów.
} 
rowy świat; tworzy iluzje, by widz poczuł, że w nich uczestniczy. Nie są one wierną kopią oryginałów klasyków, lecz kopiami autorskimi. Przetwarzając cytaty z dzieł dawnych mistrzów, białoruski twórca posługuje się techniką mieszaną i wieloma instrumentami. Stosuje cut-out, aerografię, printy (niektóre wstępnie opracowuje na komputerze), postery, rzeźbę z papieru, różnego rodzaju farby, pędzle, nożyce, klej, duże połacie papieru. Wycina, maluje, spaja elementy, po czym otrzymaną całość nakleja na wybraną ścianę i dopracowuje: dokleja z papieru udrapowania ubiorów, podmalowuje, koryguje rysunek, podkreśla, dorysowuje szczegóły, zmienia kolorystykę. Dzięki tym zabiegom uzyskuje trójwymiarowy ogląd postaci (jak w rzeźbie), tworzy iluzję wychodzenia jej z płaszczyzny ściany do pomieszczenia, na schody, na ulicę. Zastosowanie różnych rodzajów farb pozwala mu połączyć ścianę i pomieszczenie, a nadrywanie papieru „postarzyć” print. Obrazy nawarstwiane na cienką, kruchą konstrukcję materiału wyjściowego ujawniają się poprzez czas i przestrzeń jak renesansowe iluzje lub freski.

Na brudnych elewacjach budynków, w zdewastowanych pomieszczeniach, na murach ruin pojawiają się postaci kobiece z mitologii greckiej, jak Leda - królowa Sparty uwiedziona przez Zeusa pod postacią łabędzia, biblijne (Madonny z Dzieciątkiem, Maria, św. Elżbieta, Batszeba/Betsabe - żona króla Dawida, Salome), osoby świeckie (mleczarka, kobieta ważąca perły, Giovanna Cenani - żona kupca włoskiego z Lukki Giovanniego Arnolfini) itd. Busieł przedstawia je w różnych ujęciach (stoją, siedzą, wpół leżą, nachylają się w różnych kierunkach, schodzą po schodach, tańczą) lub skupia się na wizerunkach głowy, wyrazie twarzy, gestach itp.

Sztuka renesansu szczególnie upodoba sobie motyw Ledy z łabędziem. Busieł odwoła się do dwóch już nie istniejących jego ujęć. Na ściany niezamieszkanych budynków na kilku ulicach Mińska przeniesie Studium głowy Ledy (1505) (il. 1) Leonarda da Vinci do zaginionego w XVII wieku obrazu Leda $z$ łabędziem, a na mocno odrapanej, pomazanej graffiti ścianie umieści fragment obrazu Michała Anioła z 1530 roku, na którym włoski artysta prawie dosłownie przedstawia pozę kochanków. Na ruinach, znajdujących się w Łoszyckim zespole dworsko-parkowym, Busieł namaluje inne zaginione dzieło da Vinci - Bitwe pod Anghiari (1503-1506). Ta pełna ekspresji i dramatyzmu scena batalistyczna zachowa się tylko na kopiach wykonanych przez różnych malarzy (m.in. Petera Paula Rubensa) na podstawie kartonu przygotowanego przez da Vinci do niedokończonego fresku w Palazzo Vecchio we Florencji ${ }^{8}$. Smutną, zamyśloną twarz Madonny z obrazu Sandra Botticellego Madonna $z$ ksiażką (1480-1483), której malarz nadaje rysy ideału piękna włoskiego quattrocenta, artysta uliczny wykona na podwójnym tle - jasnym, imitującym płótno, które nałoży na jasnoniebieski kolor ściany z oknem (il. 2). Nawiąże w ten sposób do kompozycji oryginału, na którym Madonna z Dzieciątkiem ukazana jest na tle okna (od czasu renesansu symbolizuje ono przejście z przestrzeni zamkniętej do otwartej) z widocznym za nim błękitnym niebem i pejzażem. Postać Marii Panny w błękitnej szacie z obrazu Zwiastowanie (1434-1436, Narodowa Galeria Sztuki, Waszyngton)

\footnotetext{
8 ZÖLlner 2005, s. 76.
} 
TECHNE

T E X N H

SERIA NOWA

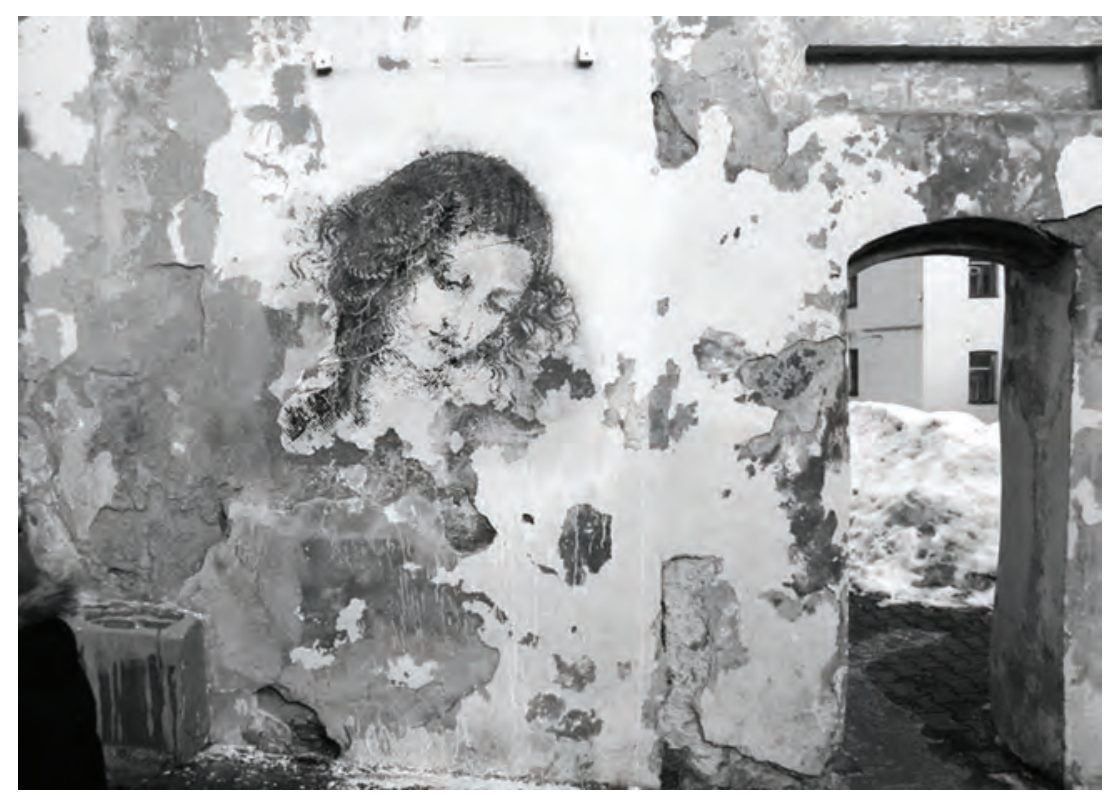

1. Andriej Busieł, Głowa Ledy według Studium głowy Ledy (1505) Leonarda da Vinci, http://paschenko.com/design/andreibusel/

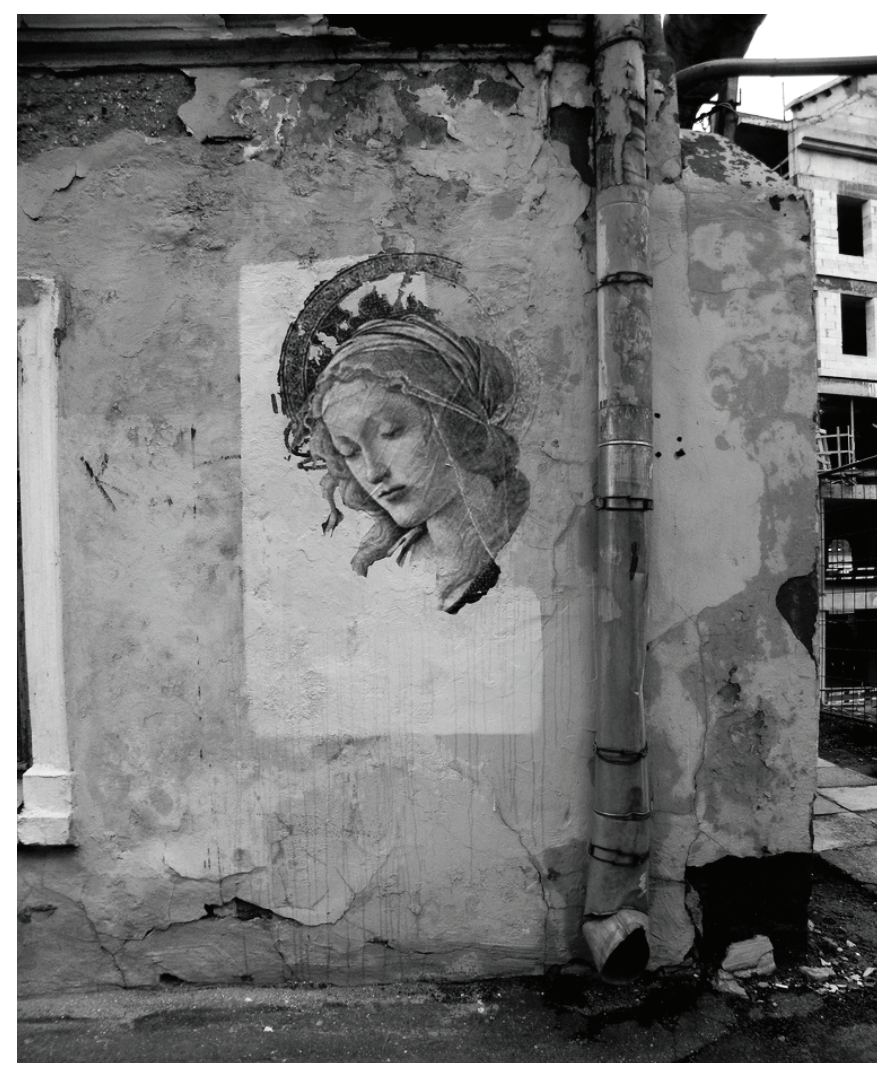

2. Andriej Busieł, Głowa Madonny (fragment) według obrazu Madonna z książką (1480-1483) Sandra Botticelliego, https://www.flickr.com/photos/26715280@N03/5265646849/in/photostream/ 
Jana van Eycka (1390-1441) - przedstawiciela realizmu niderlandzkiego, dobrze wkomponowuje się w pomalowane na biało, niszczejące pomieszczenie i jego dekoracyjne elementy architektoniczne. W zamierzeniu artysty ulicznego przestrzenność pomieszczenia oraz usytuowanie Madonny mają tworzyć iluzję „ucieczki w głąb”, co w pewien sposób nawiązuje do perspektywy i architektonicznych detali oryginału - gotyckich ostrołuków w arkadach i oknach na dole świątyni, w której Dziewica Maria odpowiada na pozdrowienie anielskie. Busieł zinterpretuje także Portret małżonków Arnolfini (1434, olej na płótnie, National Gallery, Londyn) van Eycka - pierwszy podwójny całopostaciowy portret i pierwszy portret postaci umieszczonych w półmroku wnętrza komnaty, oświetlonej przez okno9. Artysta koncentruje uwagę na, jakby bliższej widzowi, żonie kupca, spokojnej i skupionej, której poza i udrapowana zielona suknia wskazują na zaawansowaną ciążę. Zgodnie z dewizą Als ick kann („Tak, jak potrafię”), którą flamandzki mistrz sygnował swoje dzieła, Busieł stara się zbliżyć do walorów malarskiego pierwowzoru (dobrze operuje światłocieniem), z drugiej strony - poprzez dekompozycję portretu oraz przeniesienie kobiety z przeszłości do obcej współczesności, wpłynie na jej odbiór. W tonącym w półmroku pokoju Giovanna Cenani stoi w przestrzeni miejscami całkiem ciemnej i widz z trudnością może ją rozpoznać. Światło, wpadające przez otwór na drzwi, oświetla poniewierające się, zniszczone meble (kanapę, fotel), zużyte opony i inne detale zdewastowanego, już nieistniejącego mieszkania. W tym otoczeniu żona kupca nie uosabia ogniska domowego, jak na obrazie, lecz jest samotna i opuszczona jak miejsce, w którym się znajduje.

Busieł szczególnie ceni twórczość Albrechta Dürera (1471-1528) - przedstawiciela niemieckiego malarstwa renesansowego, grafika i rysownika. Spośród wielu jego wizerunków Marii z Dzieciątkiem wybiera mało znaną grawiurę Matka Boska $z$ Dzieciatkiem na trawiastej ławce/The Virgin and Child on a Grassy Bench (1503, Narodowa Galeria Sztuki, Waszyngton), która wpisuje się w przedstawienia religijne Maryi na tle „ogrodu zamkniętego” (hortus conclusus) ${ }^{10}$. Całkowite zespolenie z przyrodą, rezygnacja z reprezentacyjności nadają tu postaci Marii skromną prostotę i naturalność, przybliżają ją widzowi. Busieł dąży do wywołania podobnego wrażenia, ale przekracza granice gatunku, wprowadzając postać w szarą, przygnębiającą rzeczywistość współczesnego miasta. Postać z grawiury Dürera zamknięta w przestrzeni ciemnego, ponurego pomieszczenia, w którym jedynym źródłem światła jest okno, nie jest ani Madonną, ani świętą, lecz zwykłą mieszkanką Mińska, troskliwą matką, która musi znosić trudy codziennej egzystencji. Artystę białoruskiego fascynują także pełne ekspresji i przenikliwości, obiektywne studia starości Dürera. Rysunek, przedstawiający matkę malarza na dwa miesiące przed śmiercią (Portret matki, 1514, Staatliche Museen, Berlin-Dahlem), artysta uliczny umieści na suro-

\footnotetext{
VÉGH 1983, s. 50-51.

10 Virgin and Child on a Grassy Bench by Albrecht Dürer and five copies after it in the collection of the Polish Academy of Arts and Sciences in Cracow, http://arthistory.us/display.php?eid=50 [dostęp 14.10.2018].
} 


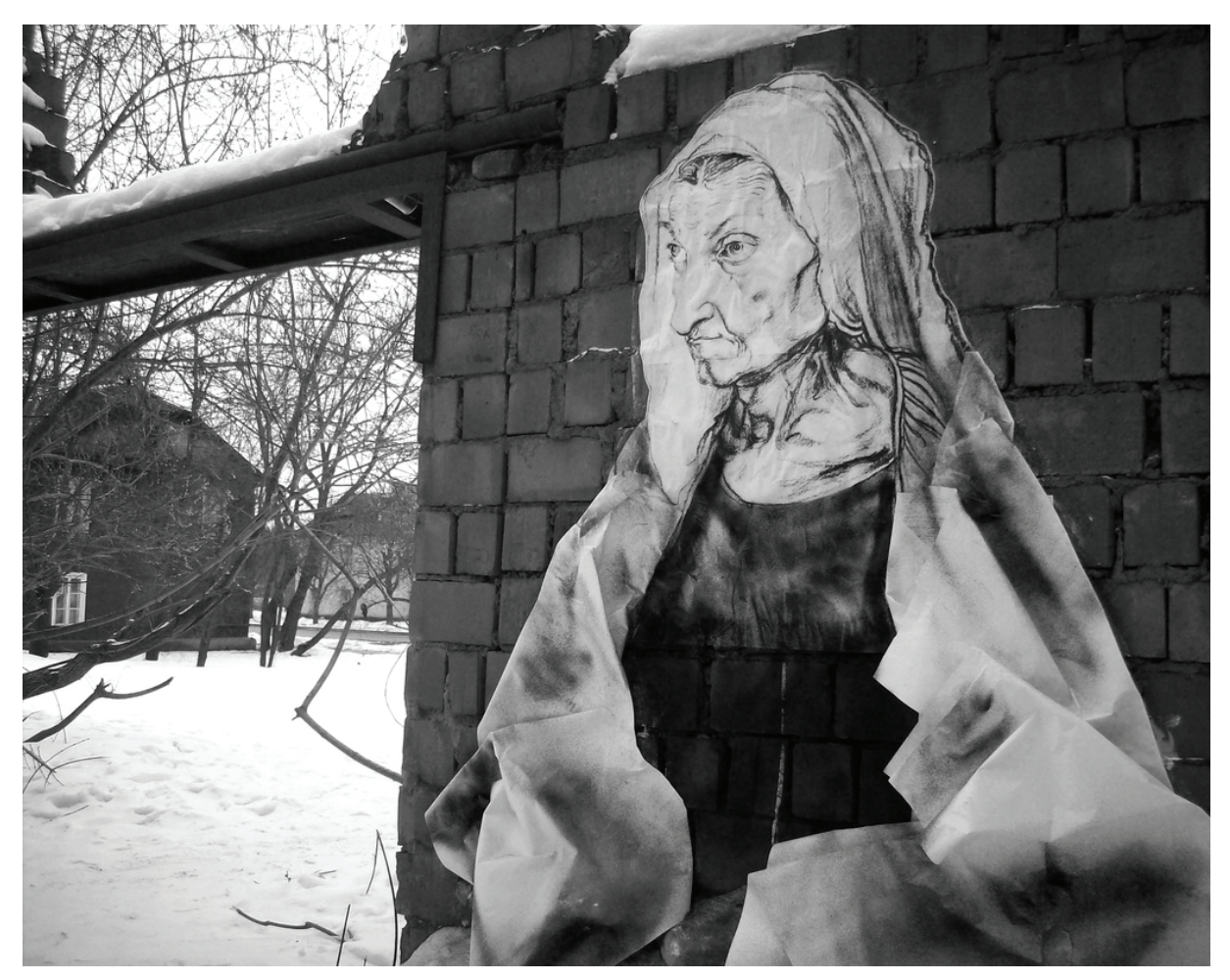

3. Andriej Busieł, Portret, według rysunku Albrechta Dürera Portret matki (1514), https://www.flickr.com/ photos/26715280@N03/3480475072/ il. 3

wym podłożu z czerwonej cegły, które wyostrza chudą twarz staruszki z zapadłymi policzkami, ostrym wąskim, długim nosem, zaciśniętymi ustami, bruzdami zmarszczek na czole, zawieszonymi w przestrzeni oczami o martwym spojrzeniu, pomarszczoną, żylastą szyję (il. 3). Głowa dziewięćdziesięciotrzyletniego starca z długą, siwą brodą, z zsuniętym do tyłu nakryciem, odsłaniającym pokryte zmarszczkami czoło (studium do namalowanego w 1521 roku malowidła na desce Święty Hieronim), koresponduje $\mathrm{z}$ osmoloną ścianą wybitego arkadowego otworu w zachowanych fragmentach ceglanych ruin. Skopiowane na zrujnowanych obiektach portrety starości ilustrują temat przemijalności czasu w sztuce i w życiu, kruchości wytworów rąk ludzkich, ulotności i nietrwałości ludzkiej egzystencji. Busieł odwoła się także do świata mody czasów Dürera, do mało znanej grawiury, przedstawiającej kobiety z Norymbergii w strojach, jakie się wówczas nosi ${ }^{11}$. Jedną z postaci, jak w wielu swoich pracach, wykona w technice cut-out i realistycznie ukaże elegancję i dostojność ruchów kobiety, schodzącej po stopniach zapuszczonej, brudnej klatki schodowej. To wrażenie spotęguje doklejając do sukni, ścielący się po schodach, bardzo długi tren z papieru. Twórcę ulicznego zainspiruje także początkowo mało znany rysunek tuszem - Dłonie apostoła (lub „Modlące się ręce”, 1508) - jeden z osiemnastu

11 Женский костюм в творчестве Альбрехта Дюрера, https://www.livemaster.ru/topic/402549zhenskij-kostyum-v-tvorchestve-albrehta-dyurera [dostęp 10.10.2018]. 


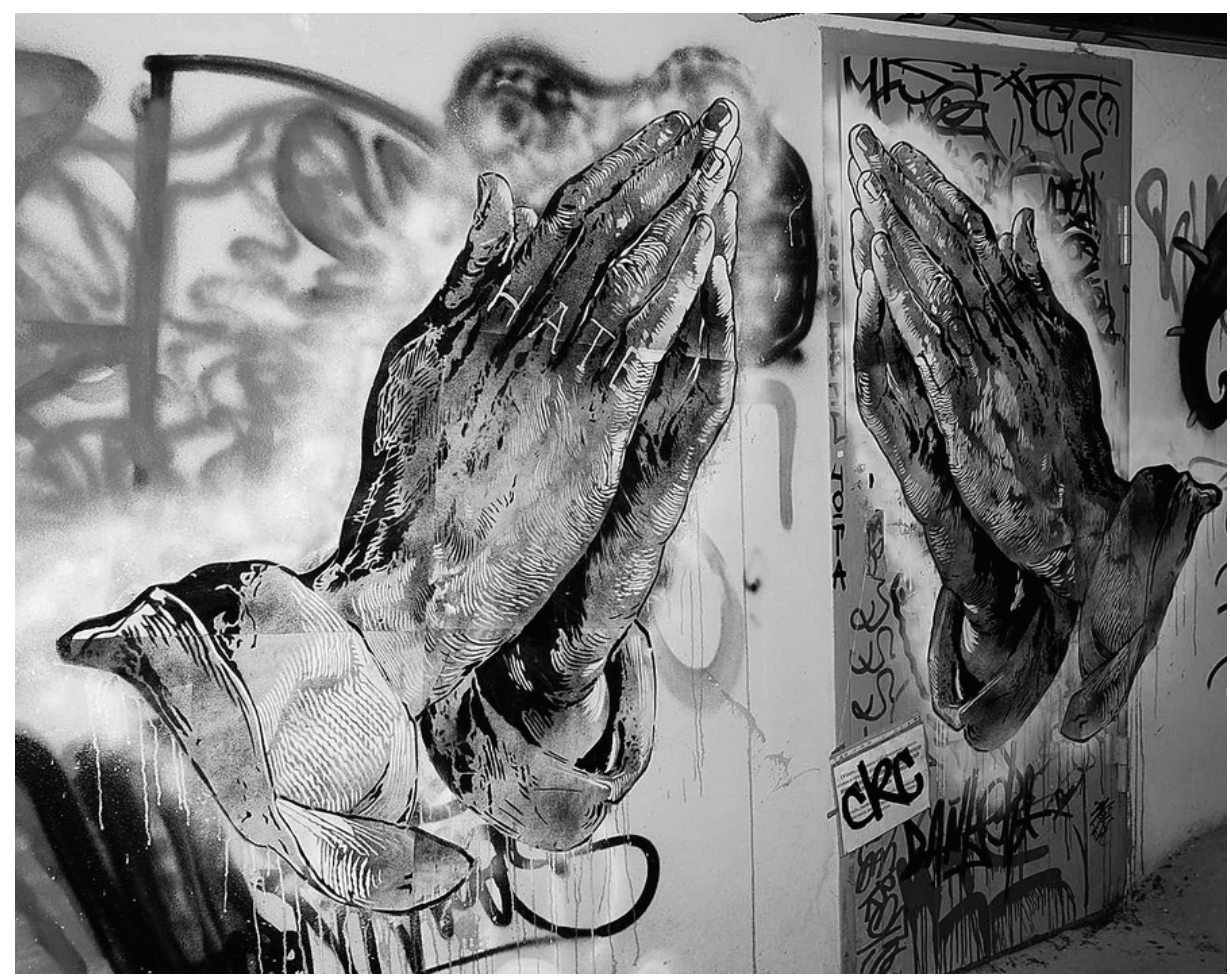

4. Andriej Busieł, Modlące się ręce według rysunku tuszem Albrechta Dürera Dłonie apostoła lub Modlące się ręce (1508), https://www.flickr.com/photos/26715280@N03/3940860290/in/photostream/

szkiców Dürera do obrazu ukazującego koronację Maryi, który zamówi kościół we Frankfurcie nad Menem. Motyw „modlących się rąk”, który od lat 50. XX wieku stanie się sławny na całym świecie jako element dekoracyjny domów oraz sakralnych i świeckich przedmiotów ${ }^{12}$, Busieł, zgodnie z założeniami ideowymi swojej sztuki, naniesie na zdewastowaną ścianę wewnątrz budynku, filar mostu i tyły trzech starych barakowozów. Ich podwójny obraz („modlące się dłonie” skierowane są ku sobie), który wykona na ścianie szczelnie pokrytej rozmaitymi formami prymitywnego graffiti (il. 4), można odczytać jako wizualny apel streetartowca skierowany do graficiarzy, by nie niszczyli miejsc publicznych lub prośbę o wzajemną tolerancję.

W Węgierskiej Galerii Narodowej, pośród wizerunków pięknych Madonn i licznych scen biblijnych, wzrok widza przykuwa wyjątkowo piękny obraz Nawiedzenie św. Elżbiety (1506), który jest ilustracją fragmentu Nowego Testamentu i przedstawia Marię odwiedzającą św. Elżbietę, po tym jak dowiaduje się, że urodzi Syna i że krewna także spodziewa się dziecka. Niezidentyfikowany twórca obrazu o inicjałach M. S. przedstawia dwie piękne, brzemienne kobiety jak spacerują i rozmawiają pośród żywej zieleni, na tle górskiego krajobrazu z widocznym

12 500-lecie „Modlacych się rąk” Albrechta Dürera, https://www.dw.com/pl/500-lecie-modlących-się-rąk-albrechta-dürera/a-3852041 [dostęp 30.10.2018]. 


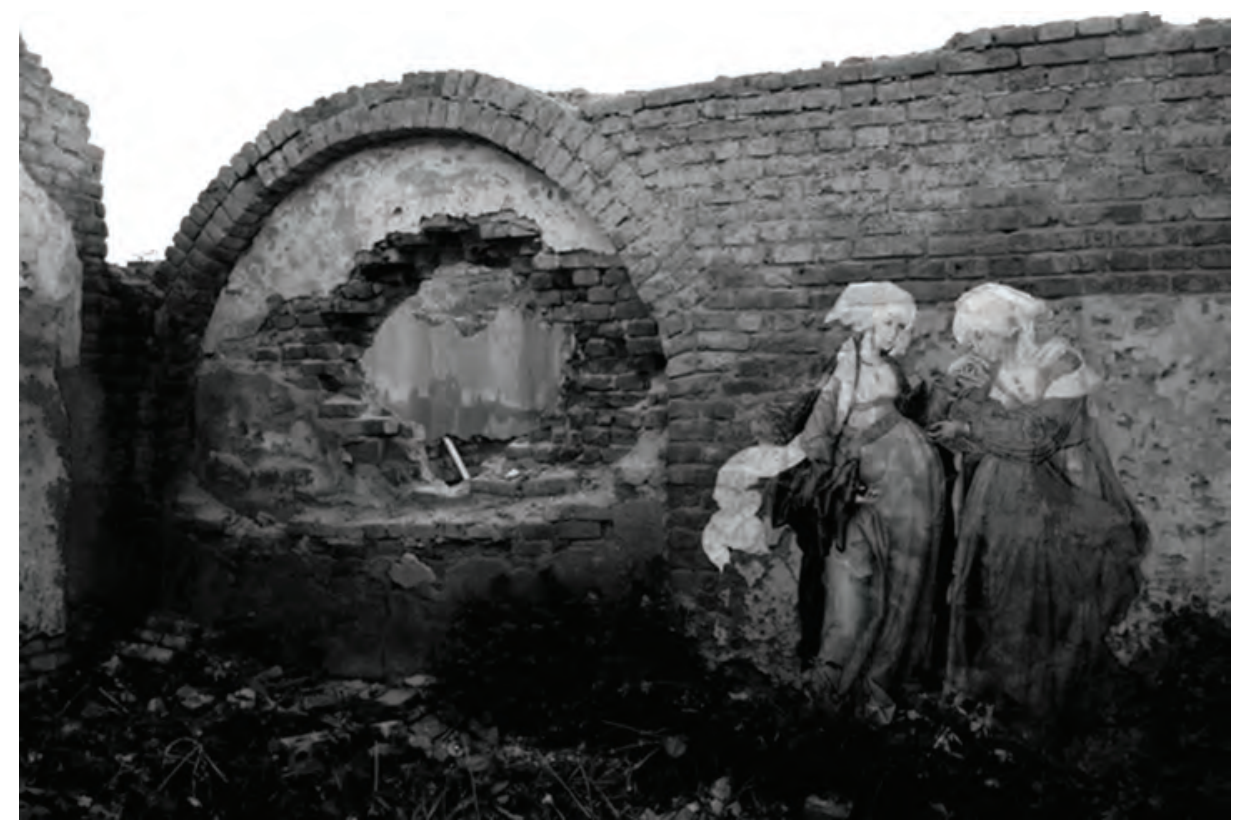

5. Andriej Busieł, Spotkanie Maryi Panny i świętej Elżbiety (fragment) według obrazu Mistrza M.S. Nawiedzenie św. Elżbiety (1506), http://paschenko.com/design/andreibusel/

w oddali fragmentem miasta. Wiatr rozwiewa ich szaty, porywa biały szal jednej $\mathrm{z}$ nich ${ }^{13}$. U ich stóp rosną szczegółowo namalowane kwiaty o symbolicznym znaczeniu. Aby oddać atmosferę obrazu, nawiązać do jego walorów wizualnych (gry mocnych, nasyconych kolorów i światła), Busieł jako podłoże dla artystycznych działań wybiera ruiny w przestrzeni naturalnego krajobrazu. Na oświetlony promieniami zachodzącego słońca mur z cegły, z uciekającymi w głąb prześwitami zamkniętymi łukiem, z rosnącą wokół trawą i chwastami, artysta naniesie pełne wdzięku, czułości, subtelnie okazywanej radości i szczęścia postaci obu kobiet - uosobienie młodzieńczej i dojrzałej kobiecości (il. 5). Dobrze odczytując zamysł Mistrza M. S., ukaże spotkanie biblijnych postaci jako świecką scenkę, osiągając podobny efekt niespodzianki. Widz, który przypadkowo trafi na tę pracę zachwyci się podobnie jak ten, który niespodziewanie ujrzy obraz w przestrzeni węgierskiej galerii.

Walory krajobrazu kulturowego Busieł wykorzysta także dla zaprezentowania krewnej Marii - Salome. Za podłoże posłuży mu nadgryziony zębem czasu, podziurawiony mur z poczerniałych cegieł, co znaczeniowo nie jest obojętne w odniesieniu do kobiety ucieleśniającej zmysłowe piękno i zło. Na ten mało estetyczny obiekt artysta uliczny przeniesie postać tańczącej Salome z fresków renesansowego włoskiego malarza doby quattrocenta Fra Filippo Lippiegio (1406-1469), które zdobią katedrę św. Szczepana w Prato. Malowidło przedstawia epizody z życia Jana Chrzciciela. W scenie Uczta u Heroda (ok. 1452-1465) delikatna, lekka jak piórko, zjawiskowo

13 Беременность в искусстве: „Взыграл младенеи во чреве её..., https://www.liveinternet.ru/ users/3596969/post157304501/ [dostęp 15.10.2018]. 


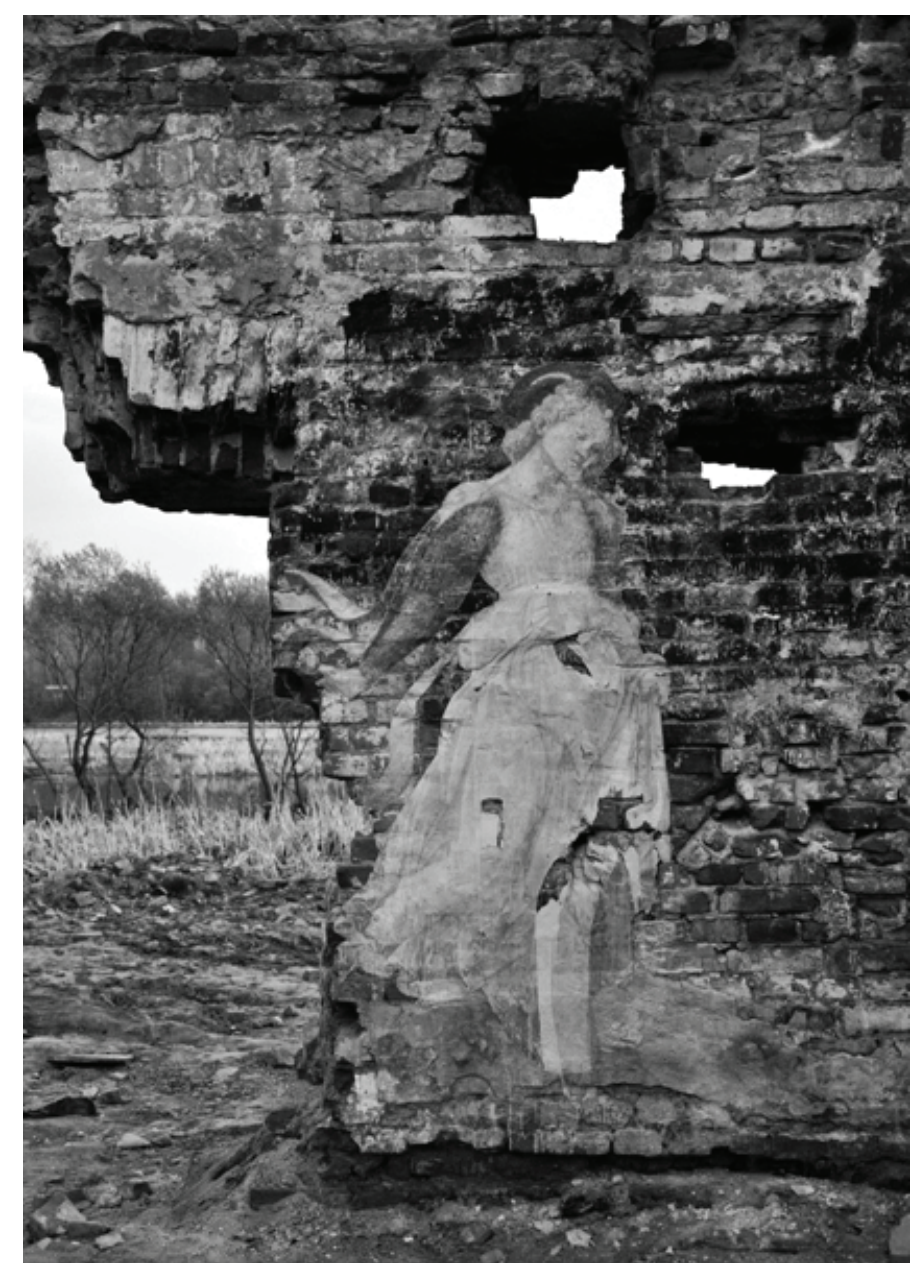

6. Andriej Busieł, SALOME (fragment) według Fra Filippo Lippiegio Uczta u Heroda (ok. 1452-1465), http://paschenko.com/design/andreibusel/

piękna córka Herodiady tańczy w białej, zwiewnej sukni i czerwonych pantofelkach na kolorowej marmurowej posadzce w przestronnej komnacie, w której ucztują Herod i jego goście ${ }^{14}$. Artyzm Lippiego przejawia się w tym, iż współczesnemu odbiorcy wydaje się, że biblijny epizod rozgrywa się "tu i teraz” i że w nim uczestniczy. Praca twórcy ulicznego wywiera inne wrażenie. „Wpasowanie” postaci Salome w przygnębiające otoczenie sprawia, że jej uroda jakby przyblakła, na twarzy maluje się jakiś nieokreślony smutek, a biała suknia (częściowo wykonana z doklejonego papieru) jest postrzępiona i dziurawa jak mur na którym tańczy. Dynamikę sylwetki poddanej rytmowi tańca zastępuje tu pewna statyczność. Ruchy są pełne wdzięku i gracji, ale nie ma w nich zmysłowości. Salome jakby zatrzymuje się w pół kroku, bojąc się zejść na rozsypany na ziemi gruz (il. 6). Całość skłania do refleksji na temat nieuchronnego upływu czasu i następujących wraz z nim niekorzystnych zmian.

\footnotetext{
14 GołaWsKa, Lindenberg 2006.
} 
W malarstwie europejskim znaczącą rolę jako temat i motyw odegra biblijna kusicielka Batszeba, przyczyna grzechu króla Dawida. Białoruskiego artystę zainspiruje jedno z jej licznych wyobrażeń - Batszeba wychodzaca z kąieli lub: Król Dawid podgladający Batszebę w kapieli (ok. 1485-1490, Staatsgalerie, Stuttgart) malarza niderlandzkiego niemieckiego pochodzenia Hansa Memlinga. Jest to jedna z dwóch części zaginionego dzieła. Malarz na wąskiej przestrzeni obrazu, na planie prostokąta pionowego, przedstawia nagą kobietę, wychodzącą z kąpieli, której służąca podaje nieskazitelnie białą, mocno pofałdowaną, obszerną koszulę. Jedna część tej szaty stanowi niemal dominantę kompozycji, druga jest niewidocz$\mathrm{na}^{15}$. Busieł zmieni format obrazu na długą powierzchnię bardzo zabrudzonej ściany na którą skopiuje postaci kobiet, doklejając do białej koszuli Batszeby brakującą jej część. Wykona ją z dużej ilości poplamionego papieru. Brudna koszula, która może wskazywać na współudział Batszeby w grzechu cudzołóstwa, ściele się po ścianie i spływa na zaśmieconą podłogę, łącząc w zamyśle artysty przeszłość z teraźniejszością. Inne emocje u widza wywołują przeniesione do współczesności dwie postaci kobiet z ołtarzowej tablicy Zdjęcie z krzyża (1435-1440) malarza niderlandzkiego XV wieku Rogiera van der Weydena (1399-1464). Na monumentalnym, kolorowym obrazie postaci mają niemal naturalne rozmiary. Wizerunki są przestrzenne, trójwymiarowe, realistyczne. Omdlałą Maryję podtrzymuje jedna z trzech niewiast spod krzyża. Aby spotęgować realizm i tragizm przeżyć Matki Boskiej Bolesnej i kobiety uczestniczącej w jej dramacie, Busieł zastosuje inne środki wyrazu: umieści niewiasty $\mathrm{w}$ wyjątkowo zapuszczonym otoczeniu, przedstawi w szarych barwach i przy pomocy techniki cut-out unieruchomi w pozie bólu i cierpienia. U widza, który przypadkowo trafi w to miejsce, obraz niewiast ma wywołać reakcję współcierpienia.

Do ciekawych interpretacji, które w pewien sposób korespondują z zastaną miejską przestrzenią, należą postaci kobiet z obrazów mistrza magii codzienności, holenderskiego malarza okresu baroku Jana Vermeera van Delft (1632-1675). Wrażenie wywiera służąca z obrazu Mleczarka albo Nalewająca mleko (1658-1660), którą Busieł zamiast w kuchni, jak na oryginale, umieści w rogu pomieszczenia z surowej czerwonej cegły, między ścianą a arkadowym oknem przez które wpada światło (tak jak na obrazie nasyca ono postać wewnętrznym spokojem) (il. 7). Służąca jest skoncentrowana i skupiona, ostrożnie i z powagą wlewa mleko do glinianego garnka, co ma uosabiać typowo holenderską cnotę panowania nad sobą. Puste, surowe pomieszczenie, które wykorzysta Busieł, dobrze komponuje się z prostą czynnością, jaką wykonuje mleczarka, a odtworzona przez niego martwa natura na stole (wierne odbicie rzeczywistości czasów malarza) ${ }^{16}$ podkreśla codzienność sytuacji. Z kolei postać skupionej, pogrążonej w myślach młodej kobiety z obrazu Vermeera Kobieta trzymająca wage (Kobieta ważąca perły lub Kobieta ważąca złoto, ok. 16621664) łączy i różnicuje dzieło sztuki malarskiej i ulicznej, zarówno na poziomie

\footnotetext{
15 Trzeciak 1976, s. 19.

16 SCHNEIder 2005, s. 61, 65.
} 


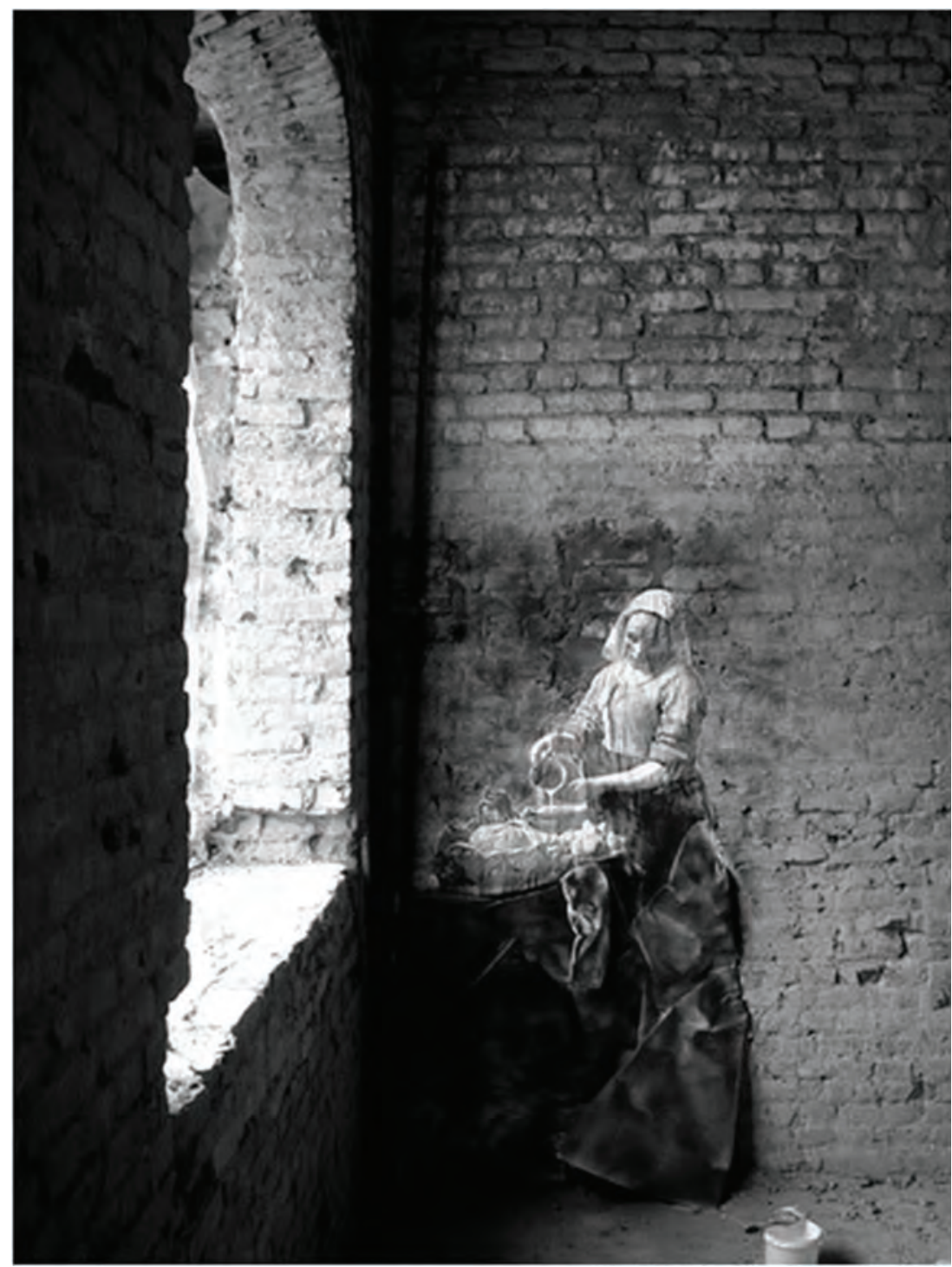

7. Andriej Busieł Mleczarka (fragment) według Jana Vermeera van Delft Mleczarka albo Nalewająca mleko (1658-1660), https://img2.mokum.place/system/images/stage1/000/010/ 541-e39ab302-1a22-4803-84ef-3b787bdc3053.jpg; http://paschenko.com/design/andreibusel/

wizualnym, jak i znaczeniowym. Busieł przeniesie postać z tonącego w półmroku pokoju w mieszczańskim domu do jasnego, ale mocno zdewastowanego pokoju szpitalnego (il. 8). Usunie też wszystkie detale, które na obrazie wiążą się z ziemskimi dobrami (perły, złoto), pozostawiając stolik o który lewą ręką opiera się kobieta, żeby się lepiej skoncentrować. U Vermeera smuga bladego światła, wpadająca przez górne okno, umiarkowanie rozjaśnia pomieszczenie, akcentując biel obszycia stroju i chustki kobiety. Busieł osiąga ten efekt sytuując postać przy oknie rozświetlonym słonecznym światłem, na tle ściany z białych kafelków i dużych arkuszy udrapo- 


\section{TECHNE \\ T E X N H \\ SERIA NOWA}

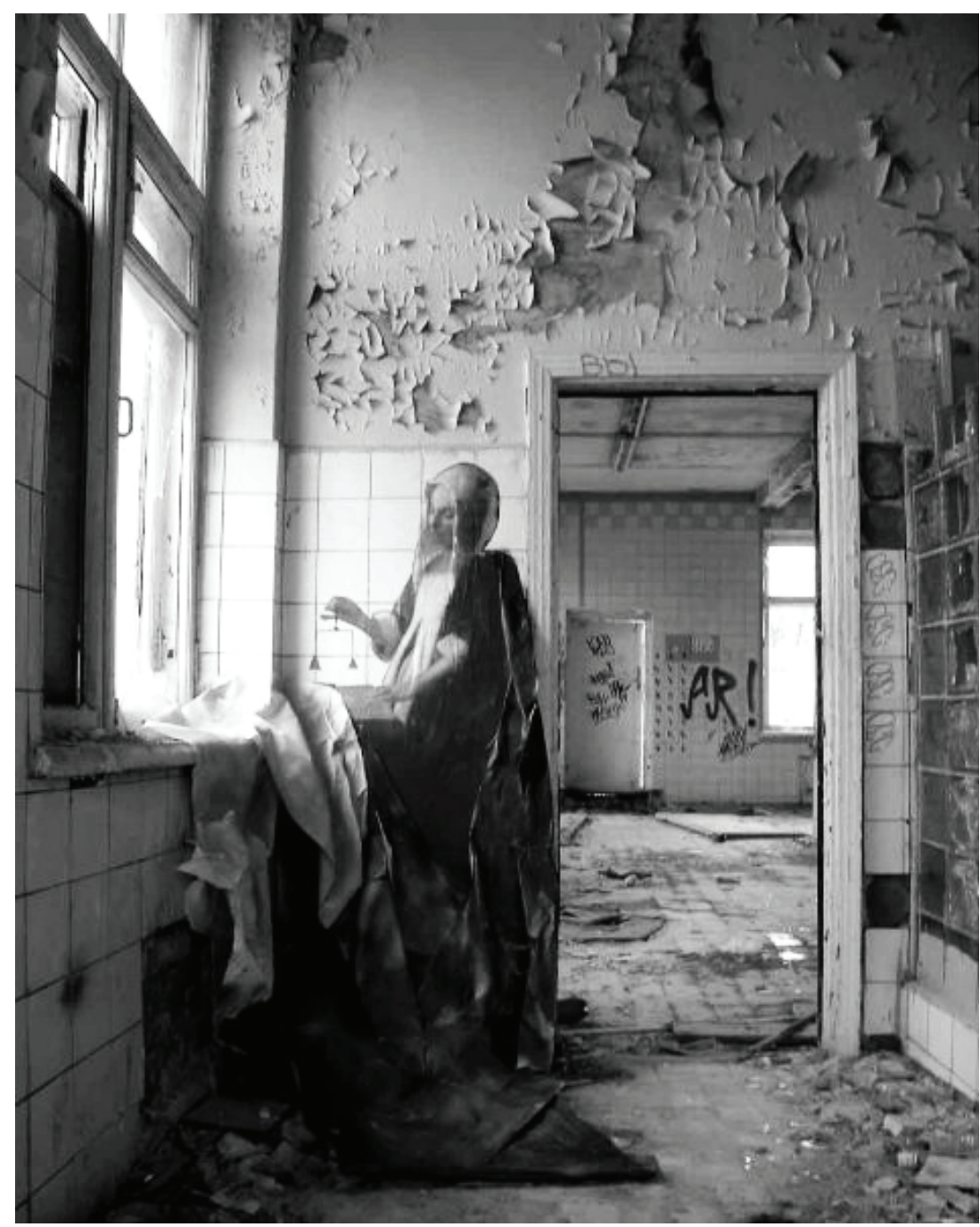

8. Andriej Busieł, Kobieta z wagą (fragment) według Jana Vermeera van Delft Kobieta trzymająca wagę (Kobieta ważąca perły lub Kobieta ważąca złoto, ok. 1662-1664),

http://paschenko.com/design/andreibusel/ il. 8

wanego białego papieru na parapecie. Doklejona szata $\mathrm{z}$ dużych połaci ciemnego papieru, która ścieli się po pełnej gruzu podłodze, sprawia, że postać nabiera cech trójwymiarowości. U Vermeera czynność ważenia nie jest jednoznaczna, może posiadać psychologiczny lub etyczny wymiar, w interpretacji artysty ulicznego, jak się zdaje, wyrównywanie wagi uosabia stan równowagi fizycznej i psychicznej, do którego dąży kobieta lub w jakim się znajduje.

W twórczości białoruskiego artysty dialog dzieł dawnej sztuki ze zrujnowaną przestrzenią współczesnego Mińska pełni różne funkcje. Prace streetartowe poprzez zmianę kontekstu i swoistą interpretację nadają nowe znaczenia dziełom klasyków i równocześnie tworzą alternatywne postrzeganie miasta, nie rewitalizują jego zaniedbane miejsca, ale na pewno zmieniają ich charakter. Widzowi, który na 
nie trafi nie pozwalają przejść obojętnie. Przeszłość współwystępuje tu z teraźniejszością, realność obrazu nakłada się na czas i zastaną rzeczywistość, przemieszaniu ulega sacrum i profanum, świętość i niezwykłość nakładają się na siermiężną codzienność Mińska. Z drugiej strony - „nieestetyczna” lokalizacja „uwolnionych” z obrazów postaci, motywów i detali wyraża i uwypukla kontrast między tym, co wieczne (sztuka wysoka) i efemeryczne (sztuka uliczna), trwałe w sztuce i szybko przemijające $\mathrm{w}$ życiu, między stworzonymi przez artystę obrazami a przygnębiającymi realiami współczesnego miasta. Z jednej strony, piękno jest wieczne, z drugiej - ulotne. Sztuka street artu według Busła nie musi być wieczna, czego dowodem są cytowane prace klasyków, które się nie zachowają.

\section{Z ulicy do galerii. Wokół zagadnień odbioru sztuki ulicznej}

Przenoszenie streetartowych prac do galerii i muzeów (w postaci foto- i wideodokumentacji lub bezpośrednio malowanych na galeryjnych ścianach) praktykowane jest na całym świecie, ale nie na Białorusi, szczególnie w Mińsku, gdzie sztuka uliczna to niezbyt aktywny kierunek subkultury, do niedawna słabo rozpoznawalny na scenie artystycznej i jak dotąd dość zamknięty. Artyści związani ze street artem uważają, iż lepiej nie ingerować za bardzo w przestrzeń miasta i światopogląd mieszkańców. Ich prace są przeważnie eksponowane daleko od miejsc publicznych i śródmiejskich ulic i niedługo funkcjonują w Internecie. Andriej Busieł jako pierwszy białoruski twórca uliczny przeniesie część swojej twórczości z przestrzeni miasta do galerii. W centrum sztuki współczesnej w Mińsku - Galeria „Ў”, w 2011 roku zaprezentuje projekt Aeternus et momentum, który okaże się ważnym wydarzeniem kulturalnym ${ }^{17}$. Kuratorzy wystawy i sam artysta deklarują, iż prezentacja prac, odwołujących się do sztuki europejskiej jest próbą zainteresowania szerokiego audytorium sztuką uliczną, zmiany jej stereotypowego postrzegania wyłącznie jako graffiti i wielkoformatowych murali usankcjonowanych przez władze, pokazania odbiorcy jak niewiele dzieli sztukę tzw. wysoką od zepchniętego na margines i nie do końca rozumianego urban artu, przybliżenia jego inspiracji, konceptów. To także próba legitymizacji artystów ulicznych z Mińska, zintegrowania środowiska białoruskich streetartowców, włączenia ich twórczości do obiegu rodzimego rynku artystycznego oraz wpisanie w najnowsze światowe trendy sztuki wystawienniczej. Dla Busła ekspozycja prac w przestrzeni galerii staje się okazją do przyjrzenia się własnej twórczości z innej perspektywy, ujawnienia tego, co na co dzień jest niewidoczne. Prace zainspirowane sztuką europejską artysta wystawi w postaci wielkoformatowych fotografii naniesionych na płótna naciągnięte na blejtramy. Rozmieści je w dwóch salach pomalowanych na biały i ciemnoszary kolor. W pierwszej wykorzysta górne oświetlenie, w drugiej - punktowe podświetlenie każdej pracy, dzięki czemu widz może „przenieść się” w miejsca, gdzie prace powstają: do suteryn, porzuconych, zniszczonych budynków z zagrzybionymi ścianami i obsypującym

17 Андрей Бусел: Aeternus et Momentum. Интервюю, http://artaktivist.org/andrej-busel-aeternus-et-momentum-2 [dostęp 15.10.2018]. 
się tynkiem, zaniedbanych klatek schodowych, brudnych przejść między domami itp., m.in. na ulicę Smoleńską, Łoszycką, Rewolucyjną, Pietrusia Browki, do Łoszyckiego parku itd. Ekspozycja ilustruje dość złożony proces twórczy mińskiego artysty, który medium sztuk plastycznych najpierw poddaje swoistej rekonstrukcji $\mathrm{w}$ przestrzeni rzeczywistej, potem utrwala je przy pomocy fotografii, by w końcu na płótno je przywrócić.

$\mathrm{Na}$ otwarcie wystawy przybędą stali bywalcy galerii, przedstawiciele i miłośnicy street art kultury oraz władz. W dyskusji, którą zorganizowano przy okrągłym stole, aktywny udział wezmą przede wszystkim streetartowcy, którzy poruszą szereg zagadnień związanych ze sztuką uliczną na Białorusi. Próbują ją na nowo zdefiniować, określić założenia, komu i czemu ma służyć, czy ewoluuje, gdzie jest jej miejsce - w przestrzeni miasta czy w galerii. Zastanawiają się nad tym, jaki wpływ na artystyczną tożsamość twórcy ulicznego oraz charakter jego sztuki ma muzealizacja street artu i czy jest słuszna, nad relacjami artysta - odbiorca, efektem niespodzianki, który zwykle towarzyszy oglądowi streetartowych prac w przestrzeni publicznej, a zatraca się w przestrzeni galerii, nad zachowaniem autentyczności autora i jego prac w warunkach wystawienniczych oraz ich wejściem na rynek artystyczny. Wystawa Aeternus et momentum spotka się z przychylnym przyjęciem, ale pojawią się także głosy krytyki. Wielość, odmienność, wizualna atrakcyjność zaprezentowanych prac Busła, chociaż wykonanych w miejscach niewidocznych, dowodzi, iż sztuka uliczna w Mińsku istnieje. Jednak, jeśli można ją oglądać tylko na fotografiach, to znaczy, że jest to sztuka martwa, że jej nie ma. Street art powinien być tylko na ulicach, tu i teraz i odbiorcy mają go oglądać na żywo. Sztuka uliczna ma wywoływać emocje, czasem też kontrowersje, ale nie ma ulegać instytucjonalizacji, festiwalizacji i komercjalizacji. Pokazane w Galerii „y̆” prace Busła nie uwikłane w przeintelektualizowane spory na temat kondycji sztuki białoruskiej, ale też nie odżegnujące się od tradycji i instytucji, to dzieła skupione przede wszystkim na tworzeniu i oddane sztuce.

\section{Zawłaszczanie przestrzeni miejskiej: obiekty, instalacje, interwencje}

Busieł pod wpływem estetyki hip-hopu i kultury punk, początkowo tworzy w stylu klasycznego graffiti ${ }^{18}$, zawłaszczając przestrzeń miejską przy pomocy pojemników farby w sprayu i wlepek (vlepki). W 2012 roku zwróci się ku sztuce land art. Artefakty, które umieszcza na łonie przyrody wpisują się w temat opozycji i koniunkcji

\footnotetext{
18 W historii białoruskiego graffiti można wyróżnić trzy fazy. Pierwsza - lata 1998-2002. Działa wówczas wiele grup związanych z graffiti kulturą, których członkowie malują wszędzie i wszystko. Część tych prac opublikuje pierwsze białoruskie czasopismo o hip-hopie „True stilo”, 2001. Jednak nie wszystkim wystarcza tagowanie. Niektórzy chçą się wyróżnić i sięgają po coraz to nowe formy wyrazu. Tak powstają pierwsze prace street artu. W 2011 roku w ramach niekomercyjnego projektu „Signal Project” ukazuje się czasopismo Olega Łariczewa „Signal”. Twórcy wspierają białoruską sztukę uliczną proponując różne formy aktywności artystycznej (wykłady, wystawy, akcje, okrągłe stoły, mural-projekty „Must Act - Must Art”). Druga faza - to połowa lat 2000. Odbywają się wów-
} 

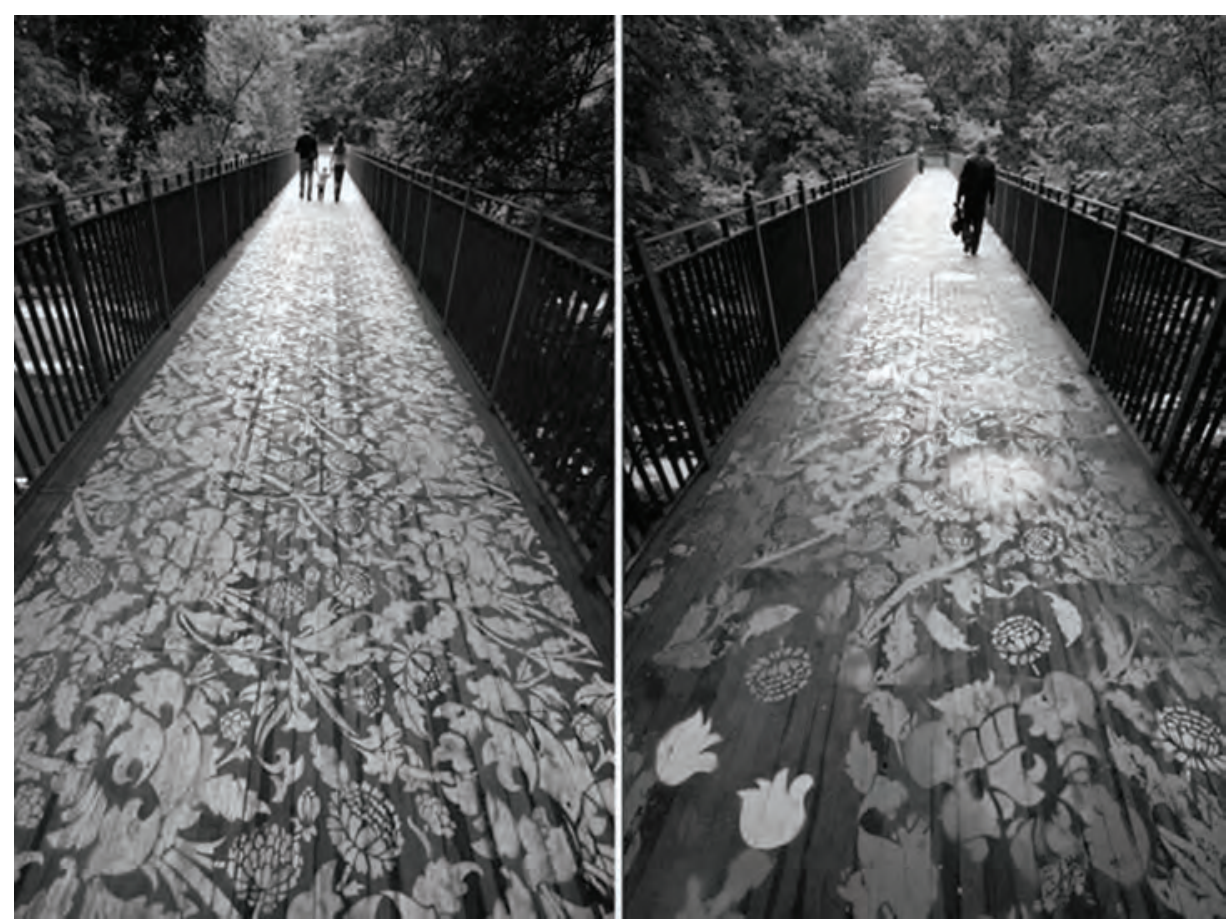

9. Andriej Busieł, Most (2012), http://artaktivist.org/toposy-i-mify-u-proekte-mixaila-gulinaduorcouyj-kompleks/

natury i kultury w ujęciu Jeana Jacka Rousseau. Uporządkowana struktura ornamentu roślinnego, którym artysta pokryje most w parku (il. 9), symbolizuje logocentryczną, zachodnioeuropejską kulturę - odsyła do sztuki dekoracyjnej modernizmu, wzorów tkanin Williama Morrisa, tapet angielskich manufaktur. Kwiaty dzikiej róży, ostrokrzewu, idealnie zaokrąglone łodygi, symetria, rytm, surowo uporządkowane formy, lakoniczne tło funkcjonują jako obraz ukulturalnionej, „oswojonej”, skrystalizowanej natury przeciwstawiając się otaczającej przyrodzie. Udekorowany sitowiem mały mostek między Łoszyckim parkiem a dzielnicą Sieriebrianka, przekształcony w obiekt artystyczny, oraz fotel z szyszek, postawiony na trawniku pod świerkiem, łączą sztukę i naturę. W 2016 roku Busieł wraz z Tarasem Paszczenką i Siergiejem Krawczenką zakłada art-grupę „Hutkasmachna studio”. Artyści ingerują w przestrzeń publiczną Mińska rozmaitymi nielegalnymi artystycznymi

czas festiwale street artu, takie jak: „Urban Myths” (2016) oraz „Vulica Brasil” (2014-2018) zorganizowany przez ambasadę Brazylii we współpracy z Ministerstwem Kultury Białorusi i Urzędem Miasta Mińska. W 2014 roku brazylijscy i białoruscy artyści uliczni zademonstrują swoje prace na ścianach Centrum Sztuki Współczesnej oraz przylegającej do niego miejskiej przestrzeni. Od tego czasu zapanuje na Białorusi moda na usankcjonowany przez władzę street art w postaci murali. Pionierem uzgodnionego z władzami Mińska street-artu jest projekt (2015) artysty Miti Pislaka, który, inspirując się monumentalnymi mozaikami okresu radzieckiego (do dziś dekorują miasto), wykonał reprodukcję obrazu Portret żony z kwiatami i owocami Jana/Iwana Chruckiego - malarza, którego dorobek traktowany jest jako część kultury polskiej, białoruskiej i rosyjskiej. W Mińsku pojawią się także instalacje. 
TECHNE

T E X N H

SERIA NOWA

działaniami i obiektami, które z założenia mają odmienić codzienny, rutynowy ogląd miasta, przybliżyć mieszkańcom sztukę street artu, zachęcić ich do współdziałania, bawić lub pobudzać do myślenia. Inicjatorem i pomysłodawcą większości poczynań jest Busieł. W działaniach grupy ważną rolę odgrywa recycling. Artyści wykorzystują i przetwarzają materiały, które pozostają Busłowi z komercyjnych zamówień lub kupują to, co jest im potrzebne. Przy ich pomocy w środowisku miejskim „odcinają niepotrzebne i dodają brakujące”. Rzadko jednakże odnoszą się do lokalnych problemów i stawiają przed odbiorcami minimalne wyzwania. W kontekst społeczny wpisują się działania Busła i Krawczenki związane z problemem ludzi bezdomnych. Temat ten zainteresuje ich z powodu bezpośredniego związku z ulicą, miastem, społeczeństwem i jego regułami. W ramach społecznego projektu „Imiona”, w którym los bezdomnych w jakimś sensie stanowi paralelę do sytuacji artystów ulicznych na Białorusi oraz przykrych doświadczeń public art, Busieł zaprezentuje instalację Sanctuary (azyl, schronienie, świątynia). Czasami grupa „Hutkasmachna studio” robi coś kontrowersyjnego, pobudzającego do myślenia i dyskusji, ryzykuje jednak, że wszystko szybko zostanie zniszczone. Barwny akcent w szary pejzaż Mińska wnosi instalacja oparta na koncepcie „bezużyteczne powinno leżeć pięknie”. Są to czerwone parasolki połączone rozpostartymi częściami, porozwieszane na krzewach wzdłuż rzeki Świsłoczy, w której się odbijają. We wszystkich działaniach streetartowcy podkreślają swoją niezależność. Dla oficjalnego projektu „Minsk Design Week” Busieł wykona, opadające na dno i wypływające na środku rzeki słowo Design. Nieco później artyści zamienią je na niejednoznaczne słowo Resign (ustąpić, zrezygnować) - swoistą formę apelu wzywającego do wprowadzenia zmian. Za ten spontaniczny gest zostaną ukarani grzywną. Ciekawą instalację, która cieszy się dużym zainteresowaniem mieszkańców Mińska, streetartowcy zatytułują Internacjonalny barok. Są to lustra oprawione w rzeźbione, drewniane ramy, własnoręcznie wykonane, porozwieszane na zniszczonych miejskich obiektach, ogrodzeniach z falistej blachy itp. (il. 10). Według zamysłu autorów, mają one pomóc mieszkańcom Mińska „odnaleźć siebie" i zmienić estetykę otoczenia. Ostatnia wspólna praca art-grupy - to fornirowy stos ustawiony przed przeznaczonym do rozbiórki budynkiem BiełEkspo (Narodowe Centrum Wystawiennicze w Mińsku). Wszystkie instalacje i obiekty grupy „Hutkasmachna” zostaną zniszczone przez służby komunalne i służby zieleni miejskiej („Zielenstroj”) ${ }^{19}$.

\section{Zamiast podsumowania. Suprematyzm po białorusku}

W ostatnich latach na Białorusi, szczególnie w Mińsku, w nurcie graffiti i street artu aktywnie rozwija się nowy rodzaj monumentalnej sztuki miejskiej - tzw. „fundamentalny suprematyzm” - „фундамэнтальны супрэматызм” (w skrócie „fuprematyzm”/ „fu-prematyzm” - „фупрэматызм”/ „фу-прэматызм” $)^{20}$. Jak wiadomo,

\footnotetext{
19 Materiał został opracowany na podstawie wielu źródeł pochodzących z Internetu.

20 Ольга и Денис Архиповы, «Фупрематизм», http://artaktivist.org/fuprematyzm [dostęp 17.10.2019]. W języku białoruskim artykuł ukaże się w czasopiśmie „pARtizan” 2011.
} 


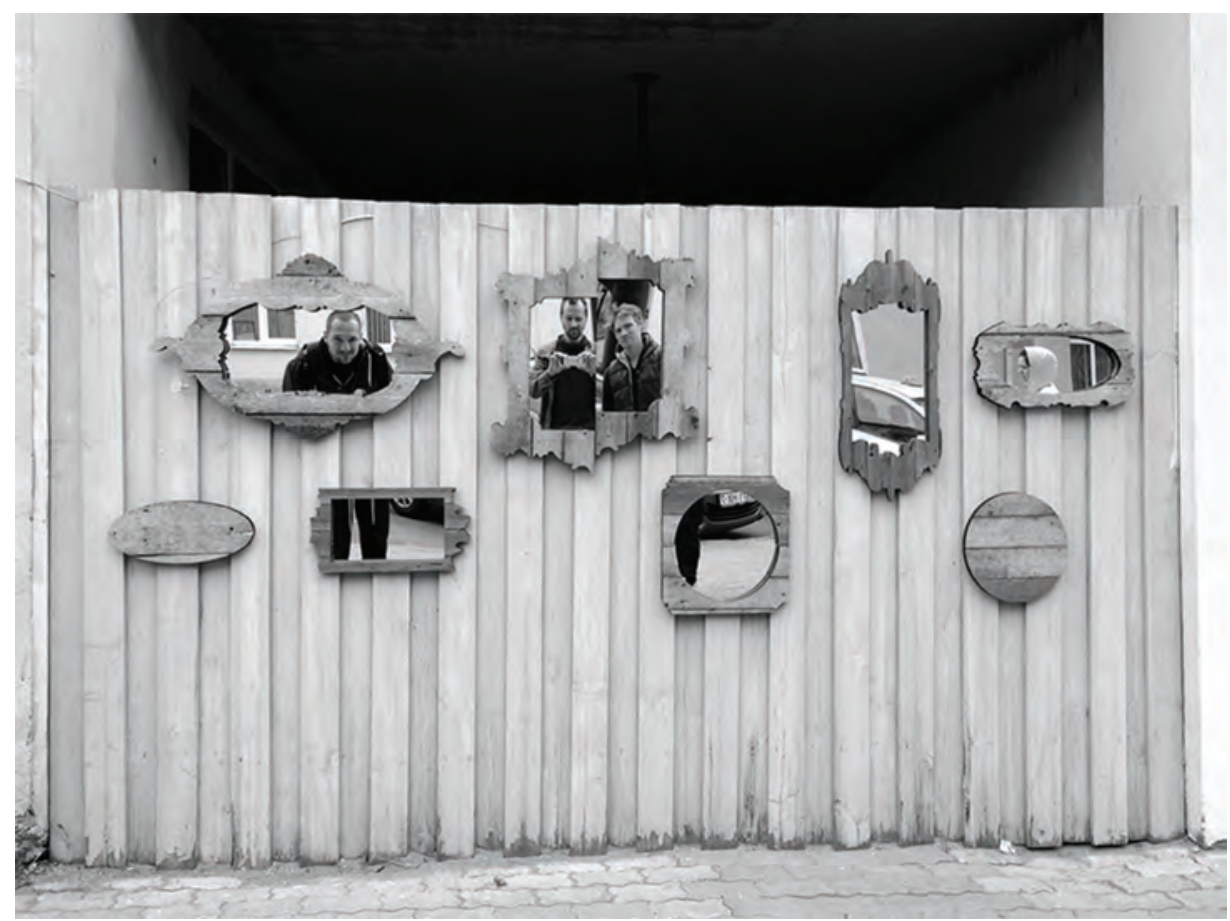

10. Andriej Busieł, Internacjonalny barok (2016), http://paschenko.com/publicart/mirrors.jpg

suprematyzm, zgodnie z założeniami jego twórcy Kazimierza Malewicza, zakłada oderwanie sztuki od rzeczywistości, dążenie do maksymalnego uproszczenia form, zerwania z narracją i przedmiotowością w sztuce. Określenie „fundamentalny” wskazuje na masowy, narodowy charakter nowej sztuki i dużą liczbę uczestników zdarzeń. Neologizm „fuprematyzm” powstanie spontanicznie w środowisku profesjonalnych graficiarzy, którzy na podstawie formalnych oznak i skali zjawiska tak określą, pretendującą do miana sztuki niezależnej, twórczość anonimowych, nieprofesjonalnych „artystów”, tj. pracowników służb miejskich, którzy z poczucia obowiązku zamalowują twórczość wandali, opozycyjnych aktywistów, piłkarskich fanatyków, graficiarzy i streetartowców. Na fasadach domów, budynków instytucji pojawia się niezliczona ilość kompozycji, składających się z asymetrycznych, prostokątnych i kwadratowych płaszczyzn. Kolorystyczne rozwiązania tych malowideł są rozmaite. Jest to szerokie spektrum odcieni barw, które z reguły nieco różnią się od podstawowego koloru ściany. Najlepsze wzory „fuprematycznych” kompozycji - nakładające się jedna na drugą proste formy geometryczne, powstają w bramach i przejściach. Z estetycznego punktu widzenia zjawisko to funkcjonuje na granicy różnych kategorii: tego co brzydkie, prymitywne, fundamentalne, masowe, nieprofesjonalne, narodowe, komiczne, oficjalne i niezrozumiałe. W publicznej przestrzeni Mińska „fuprematyzm” to nieodłączny element codzienności, powszechnie dostępna sztuka sankcjonowana przez społeczeństwo i państwo. „Fuprematyzm” jako „społecznie znaczące zjawisko” jest najprostszą formą, w której odzwierciedla 
się współczesna sytuacja na Białorusi - wszechobecna cenzura. „Fuprematyczne” malowidła - to milczący świadkowie „demokracji i wolności słowa” oraz działań artystów ulicznych w tym kraju. Sztuka ta może trwać wiecznie, gdyż spotyka się z interakcją graficiarzy, którzy na kolektywne dzieła pracowników służb komunalnych niemal natychmiast nakładają swoją indywidualną twórczość.

\section{Bibliografia}

\section{Opracowania}

Bisкupsкi 2017 - Łukasz Biskupski, Prosto z ulicy. Sztuki wizualne w dobie mediów społecznościowych i kultury uczestnictwa, Warszawa 2017.

Boвılewicz 2016 - Grażyna Bobilewicz, Есенин и его поэзия в стиле стрит-арт и пабликapm, „Соврменное есениноведение”, Рязань 2016, № 2 (37), s. 27-41.

BoвıLewicz 2016 - Grażyna Bobilewicz, Уличные игры с Владимиром Маяковским, [w:] Пятнами красок, звоном тозунгов..." Книжно-плакатное творчество В.В. Маяковского. Составитель, ответственный редактор В.Н. Тарехина. Редколлегия: В.Н. Дядичев, А.П. Зименков, Н.В. Михаленко, В.Н. Тарехина (сост., отв. ред.), А.М. Ушаков, Москва, Санкт-Петербург 2016, s. 276-286.

Boвılewicz 2017 - Grażyna Bobilewicz, Поэт в уличной галерее. Портреты Сергея Есенина и Владимира Маяковского, Русская филология. Ученые записки (журнал) кафедры литературы и журналистики Смоленского государственного университета. Ред. М.Л. Рогацкина, Е.Л. Котова, А.А. Азаренков, Т. 17, Смоленск 2017, s. 29-52.

Dymna/Rutkiewicz 2012 - Elżbieta Dymna, Marcin Rutkiewicz, Polski street art. Wydanie nowe, Warszawa 2012.

Ganz 2008 - Nicholas Ganz, Świat graffiti: sztuka ulicy z pięciu kontynentów. Pod red. Tristana Manco (tłum. Piotr Amsterdamski), Warszawa 2008.

Goławska/Lindenberg 2006 - Anna Maria Goławska, Grzegorz Lindenberg, Toskania, Umbria i okolice. Przewodnik subiektywny, Warszawa 2006.

GralińsKa-Toborek/Kazimierska-Jerzyk - Agnieszka Gralińska-Toborek, Wioletta Kazimierska-Jerzyk, Doświadczenie sztuki w przestrzeni miejskiej. Galeria Urban Forms 2011-2013. Experience of Art in Urban Space Urban Forms Gallery 2011-2013, tłum. Marta Koniarek, Biblioteka/Urban Forms Foundation, Łódź 2014, s. 11-23.

Gralińska-Toborek - Agnieszka Gralińska-Toborek, Graffiti i street art. Słowo - obraz - działanie, Łódź 2019.

Мосн 2016 - Włodzimierz Moch, Street art i graffiti. Litery, słowa i obrazy w przestrzeni miasta, Bydgoszcz 2016.

SCHNEIDER 2005 - Norbert Schneider, Vermeer. 1632-1675. Ukryte emocje, Warszawa 2005.

Trzeciak 1976 - Przemysław Trzeciak, Hans Memling, Warszawa 1976.

VÉGH 1983 - János Végh, Van Eyck, Warszawa 1983. 
Virgin and Child on a Grassy Bench by Albrecht Dürer and five copies after it in the collection of the Polish Academy of Arts and Sciences in Cracow, http://arthistory.us/display.php?eid=50 [dostęp 14.10.2018].

ZÖLLNER 2005 - Frank Zöllner, Leonardo da Vinci 1452-1519, Warszawa 2005.

500-lecie „Modlących się rąk” Albrechta Dürera, https://www.dw.com/pl/500-lecie-modlących-się-rąk-albrechta-dürera/a-3852041 [dostęp 29.10.2018].

Ольга и Денис Архиповы, «Фупрематизм», http://artaktivist.org/fuprematyzm [dostęp 17.10.2019].

Андрей Бусел: Aeternus et Moтеntuт. Интервью, http://artaktivist.org/andrej-busel-aeternus-et-momentum-2 [dostęp 15.10.2018].

Женский костюм в творчестве Альбрехта Дюрера, https://www.livemaster.ru/topic/402549zhenskij-kostyum-v-tvorchestve-albrehta-dyurera [dostęp 10.10.2018].

Беременность в искусстве: „Взыграл младенеи во чреве её..., https://www.liveinternet.ru/ users/3596969/post157304501/ [dostęp 15.10.2018]. 


\section{The works of Andrei Busel, a Belarusian street artist}

$\mathrm{T}$ he study focuses on unexamined representations and miscellaneous instances of the diverse creativity of the Belarusian street artist, Andrei Busel (also known as Hutkasmachna). The study was based on interpretative works analysing Busel's artistic forms of expression: Eternal in Passing. Artwork of European Masters in the Public Space of Minsk, From Streets to Art Gallery. On Reception of Street Art, and Appropriation of Urban Space: Objects, Installations, Interventions. On the basis of selected examples, an analysis of interpretations of relatively obscure works by European masters was performed, as they were placed by Busel in dilapidated and rundown parts of Minsk. These were works by such artists as Leonardo da Vinci, Michelangelo, Sandro Botticelli, Jan van Eyck, Albrecht Dürer, Hans Memling, Jan Vermeer van Delft. When processing the fragments from their works, he applied a mixture of techniques and tools (cut-out, airbrush, prints, posters, paper sculptures, various types of paints, brushes, scissors, glue, and massive sheets of paper). Busel is the first Belarusian artist to move some of his works from the urban space into a gallery (project: Aeternus et momentum,

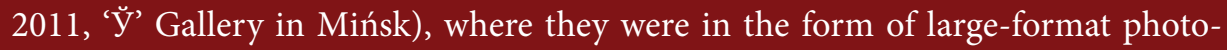
graphs mounted on stretcher bars. The exposition illustrated his artistic creative process: firstly, he reconstructed the European masterpieces in a real space before photographing them, and eventually, using the photographs to redisplay them on canvas. The article also presents other forms of Busel's illegal appropriation of urban space, such as street-art objects, installations and interventions, e.g., Bridge (2012), or International Baroque. Another issue discussed in the final section of the article is a brand new street-art trend developing in Belarus - the so-called fundamental suprematism (abbreviated to 'fuprematism'), i.e., the visual interaction of municipal services with the output of Minsk-based street artists. 